\title{
STRATEGI PENGEMBANGAN SEKTOR PERIKANAN DALAM MENINGKATKAN PENDAPATAN ASLI DAERAH (PAD) KABUPATEN FLORES TIMUR PROVINSI NUSA TENGGARA TIMUR
}

\author{
Oleh \\ Vinsensius Fererius Payong ${ }^{1}$, \\ Muh. Ilham ${ }^{2}$ Bambang Supriadi ${ }^{3}$ \\ 1) Institut Pemerintahan Dalam Negeri \\ Program Magister Terapan Studi Pemerintahan Daerah Institut Pemerintahan Dalam Negeri \\ vinsensiusfereriuspayong@yahoo.com \\ 2,3) Institut Pemerintahan Dalam Negeri
}

\begin{abstract}
“FISHERY SECTOR DEVELOPMENT STRATEGY IN INCREASING THE REGIONAL NATIVE INCOME (PAD) OF EAST FLORES REGENCY, EAST NUSA TENGGARA PROVINCE”
\end{abstract}

$T_{\mathrm{r}}^{\mathrm{h}}$

This research focuses on the development of the fisheries sector in increasing the Original Regional Income of East Flores Regency. The purpose of this research is to find out and analyze the development of the fisheries sector in East Flores Regency, to analyze the factors that become obstacles in the development of the fisheries sector, and to provide input to local governments on good strategies in developing the fisheries sector so that they can make a good contribution to Regional Original Income (PAD) East Flores Regency.

The theory used in this research is the development theory by Kusumastanto (2003) regarding fisheries development which has 1 (one) dimension, namely the policy to develop capture fisheries: fuel subsidies for fishermen, fishing operation licensing regulations, related policies (Supporting), Advocacy and diplomacy. Development policies related to infrastructure and policy support. The approach used in data analysis. The approach used in data analysis is the SWOT analysis and the Litmus Test which is to analyze the appropriate strategies in the development of the fisheries sector in East Flores Regency.

The results showed that the development of the fisheries sector in East Flores Regency has not been carried out optimally. Because it still has several deficiencies in the existing fisheries development process, including aspects of fish resources, aspects of production, aspects of human resources (HR), aspects of facilities and infrastructure, aspects of marketing and aspects of economy. Suggestions from this study are given the promising potential of fisheries and the source of the budget for development financing (PAD) of East Flores Regency, it is necessary to have a recommended policy containing comprehensive rational assumptions, so presumably some policy alternatives should be able to become a series of activities/policies that will mutually support and complement (synergy). Because this will certainly provide more optimal results as expected by the local government and fishing communities in East Flores Regency in the context of the current implementation of regional autonomy.

Keywords: development, fisheries, regional original income 


\begin{abstract}
ABSTRAK
$\mathrm{P}$ enelitian ini terfokuskan pada Pengembangan sektor Perikanan tangkap dalam meningkatkan Pendapatan Asli Daerah Kabupaten Flores Timur. Tujuan penelitian ini adalah untuk mengetahui dan menganalisis pengembangan sektor perikanan di Kabupaten Flores Timur, menganalisis faktor yang menjadi kendala dalam pengembangan sektor perikanan, dan memberikan masukan kepada pemerintah daerah strategi yang baik dalam pengembangan sektor perikanan sehingga mampu memberikan kontribusi yang baik terhadap Pendapatan Asli Daerah (PAD) Kabupaten Flores Timur.

Teori yang digunakan dalam penelitian ini adalah teori pengembangan oleh Kusumastanto (2003) tentang Pengembangan perikanan yang memiliki 1 (satu) dimensi, yaitu Kebijakan mengembangkan perikanan tangkap: Subsidi BBM untuk nelayan, Regulasi perizinan operasi penangkapan ikan, Kebijakan terkait (Supporting), Advokasi dan diplomasi, Kebijakan pengembangan Terkait dukungan infrastruktur dan kebijakan. Pendekatan yang digunakan dalam analisis data Pendekatan yang digunakan dalam analisis data, yaitu analisis SWOT dan Litmus Test yang untuk menganalisis strategi yang dapat tepat dalam Pengembangan Sektor Perikanan di Kabupaten Flores Timur.

Hasil penelitian menunjukkan bahwa pengembangan sektor perikanan di Kabupaten Flores Timur belum dilakukan secara optimal. Karena masih memiliki beberapa kekurangan dalam proses pengembangan perikanan yang ada antara lain Aspek sumber daya ikan, Aspek Produksi, Aspek Sumber Daya Manusia (SDM), Aspek sarana dan prasarana, Aspek Pemasaran dan Aspek Ekonomi. Saran dari penelitian ini, yaitu Mengingat potensi perikanan yang menjanjikan dan sumber anggaran pembiayaan pembangunan terkhusus (PAD) Kabupaten Flores Timur perlu adanya kebijakan yang direkomendasikan mengandung asumsi rasional komprehensif, maka kiranya beberapa alternatif kebijakan hendaknya dapat menjadi suatu rangkaian kegiatan/kebijakan yang satu sama lain akan mendukung dan melengkapi (sinergi). Karena hal tersebut tentunya akan lebih memberikan hasil yang optimal sebagaimana yang diharapkan oleh pemerintah daerah serta masyarakat nelayan di Kabupaten Flores Timur dalam rangka pelaksanaan otonomi daerah saat ini.
\end{abstract}

Kata kunci: pengembangan, perikanan, pendapatan asli daerah

\section{PENDAHULUAN}

$\mathrm{I}$ su strategis dan permasalahan umum yang menjadi kendala utama dalam mewujudkan kegiatan perikanan berkelanjutan di Indonesia adalah: 1) pengelolaan perikanan (fisheries management); 2) penegakan hukum (law enforcement); dan 3) pelaku usaha perikanan. Masih lemahnya sistem pengembangan perikanan merupakan isu strategis dan permasalahan umum yang pokok dalam mewujudkan sektor perikanan berkelanjutan di Indonesia.

Keberhasilan pelaksanaan pembangunan di wilayah kelautan dan perikanan, belum terlihat di Provinsi Nusa Tenggara Timur, karena, pengembangan produksi ikan di Provinsi Nusa Tenggara Timur, belum maksimal akibat berbagi kendala yang dihadapi nelayan. Pemerintah pun diminta memberikan berbagai bantuan dan kemudahan. Porsi perizinan yang menjadi kewenangan pusat perlu didelegasikan kepada Provinsi Nusa Tenggara Timur. Penyederhanaan prosedur juga perlu dilakukan disesuaikan dengan kondisi wilayah. Perda No. 04/2007 tentang Rencana Zonasi Wilayah Pesisir dan Pulau-Pulau Kecil, yang menutup ruang nelayan perlu direvisi agar nelayan bisa diberi ruang yang luas dalam menangkap ikan. Pemerintah perlu mendorong perluasan mata pencarian warga berbasis kemaritiman yang ramah lingkungan dan berkeadilan. (bed de Rosary [Kupang] di 27 May 2019). 
Kedudukan Kabupaten Flores Timur sebagai salah satu daerah otonom, maka Pemerintah Daerah Kabupaten Flores Timur mempunyai kewenangan dalam mengatur dan mengurus rumah tangganya sendiri. Sesuai dengan Peraturan Daerah Kabupaten Flores Timur No. 13 Tahun 2008 tentang Rencana Tata Ruang Wilayah Kabupaten Flores Timur Tahun (2007 - 2027), yang terdiri dari 19 Kecamatan terbagi ke dalam 229 Desa dan 21 Kelurahan. Dengan luas perairan Kabupaten Flores Timur melebihi luas daratan, yakni $5.983,38 \mathrm{~km} 2$. Yang terdiri dari Luas daratan $1.812,85 \mathrm{~km} 2$ dan luas perairan sekitar 4.170,53 km2, maka bisa disimpulkan bahwa sektor perikanan memiliki potensi yang sangat menjanjikan dalam meningkatkan Pendapatan Asli Daerah (PAD).

Beberapa faktor yang masih menjadi kendala dan tantangan Pemerintah Kabupaten Flores Timur saat ini dalam pengembangan sektor perikanan. Pada RPJMD Kabupaten Flores Timur Tahun 20172022 antara lain: Peningkatan produksi perikanan belum diikuti dengan penggunaan sarana tangkap yang ramah lingkungan, belum berkembangnya budi daya perikanan laut dan air tawar, sarana dan prasarana penunjang untuk mengoptimalkan pemanfaatan, potensi perikanan masih terbatas, keterbatasan tenaga penyuluh dan penyuluhan perikanan, maraknya kasus pencurian ikan (Illegal Fishing), penangkapan ikan menggunakan bahan peledak (bom) dan zat-zat kimia seperti potassium, sianida dan zat aditif lainnya masih banyak, tingginya penangkapan biota/mamalia laut yang dilindungi, masih banyak kegiatan penambangan pasir laut dan pengrusakan terumbu karang, masih banyak terjadi penebangan hutan mangrove, masih tingginya pencemaran laut melalui pembuangan limbah rumah tangga maupun limbah lainnya.

\section{METODE PENELITIAN}

Penelitian ini menggunakan metode penelitian kualitatif dengan pendekatan deskriptif. Alasannya karena peneliti ingin menggambarkan mengenai keadaan yang sebenarnya di tempat penelitian Tujuan penggunaan desain penelitian deskriptif pada penelitian ini adalah mencari pemahaman makna berdasarkan fakta atau kenyataan yang ada di lokasi penelitian, kemudian dilakukan penelaahan agar diperoleh gambaran yang jelas dan sistematis dalam rangka pemecahan masalah yang dihadapi.

\section{HASIL PENELITIAN DAN PEMBAHASAN}

\section{Kebijakan Pengembangan Sektor Perikanan di Kabupaten Flores Timur}

Pengembangan perikanan yang selama ini dilakukan pemerintah di Kabupaten Flores Timur dalam layanan urusan terkait sektor perikanan. Perikanan tangkap sebagian besar dilakukan di laut, terutama di sekitar pantai dan landasan kontinen. Perikanan tangkap juga ada di danau dan sungai. Masalah yang mengemuka di dalam perikanan tangkap adalah penangkapan ikan berlebih dan polusi laut. Sejumlah spesies mengalami penurunan populasi dalam jumlah yang signifikan dan berada dalam ancaman punah. Hal ini mengakibatkan jumlah tangkapan ikan di alam liar dapat mengalami penurunan secara umum. Berlawanan dengan perikanan tangkap, perikanan budi daya dioperasikan di daratan menggunakan kolam air atau tangki, dan di badan air yang terpagari sehingga organisme air yang dipelihara tidak lepas ke alam liar.

Penulis menggunakan teori Kusumastanto ini guna untuk mengukur seberapa jauh kebijakan pemerintah dalam untuk memfokuskan pada pembangunan ekonomi masyarakat dengan kebijakan ekonomi berbasis komoditas budi daya perikanan tangkap di Kabupaten Flores Timur. Selanjutnya, menurut Kusumastanto 
(2003), beberapa kebijakan yang saat ini urgent dilakukan guna menyelamatkan dan mengembangkan perikanan tangkap di Indonesia, adalah:

a. Subsidi BBM untuk nelayan.

b. Regulasi terhadap permasalahanpermasalahan mendasar seperti ilegal, unreported dan unregulated fishing, serta persoalan yang menyangkut perizinan terhadap operasi penangkapan ikan.

c. Kebijakan yang terkait dengan dukungan (supporting) pendanaan dan investasi.

d. Advokasi dan diplomasi perikanan seperti: peningkatan partisipasi Indonesia dalam perikanan regional, utamanya sebagai anggota (concracting party) dari Indian Ocean Tuna Commission (IOTC) dan kebijakan ini untuk membuka akses Indonesia sebagai pemanfaat dan membuat Indonesia memiliki kuota produksi dan kuota pasar internasional serta menghindari Indonesia dari kemungkinan embargo produk perikannya.

e. Kebijakan pengembangan perikanan terpadu lintas sektoral yang sustainable, hulu-hilir dimulai dari fishing ground pelabuhan perikanan pasar.

Berdasarkan pengamatan di lapangan perairan Kabupaten Flores Timur memiliki karakteristik karena memiliki kekayaan sumber daya hayati laut yang tinggi. Namun pengembangan yang dilakukan tidak secara merata dan berkelanjutan.

Salah satu sumber daya alam hayati Flores Timur terletak di bidang perikanan baik itu dari perikanan laut (ikan tangkap) termasuk di dalamnya bermacam-macam kegiatan seperti menyimpan, mendinginkan, mengawetkan maupun mengelolanya yang kemudian diekspor ke luar negeri, dilihat dari perikanan darat (tambak, waduk, jaring, rawa, dan sejenisnya). Kegiatan tersebut dilakukan untuk tujuan komersial yang mendatangkan penghasilan dan keuntungan bagi manusia.
Dari penjelasan dan pengamatan yang dilakukan dapat dianalisis, bahwa sudah adanya program prioritas untuk peningkatan daya saing potensi unggulan daerah, khususnya sektor perikanan. Namun, arah pengembangannya belum dirasakan secara spesifik.

\section{- Subsidi BBM untuk Nelayan}

Langkah yang telah diambil Dinas Perikanan Flores Timur adalah penimbunan BBM (Perda No. 2/2004). Hasil analisis menunjukkan bahwa operasional pendistribusian BBM bersubsidi selama ini diawasi agar lebih tepat sasaran sesuai dengan skala usaha penangkapan. Kemudian untuk menjamin tersedianya pasokan BBM bersubsidi dengan harga yang terjangkau nelayan, perlu dilakukan hal-hal sebagai berikut.

a. Mengaktifkan SPDN (solar packed dealer nelayan) yang sudah dibangun namun belum beroperasi;

b. Membangun SPBU (stasiun pengisian bahan bakar) mini khusus nelayan dengan armada < 5 GT; dan

c. Mengawasi penyaluran BBM bersubsidi agar lebih tepat sasaran.

Dapat disimpulkan dari hasil wawancara dan pengamatan di lapangan bahwa belum optimalnya bantuan subsidi BBM dari Pemerintah Kabupaten Flores Timur dan Dinas Perikanan kepada Pelaku Perikanan.

\section{- Regulasi perizinan operasi penangkapan ikan}

Adapun produk hukum tentang perizinan usaha yang membahas izin usaha perdagangan, pergudangan yang termuat pada Peraturan Daerah No. 11/2002, industri Peraturan Daerah No. 5/2005, perikanan Peraturan Daerah No. 4/2006, dan penimbunan BBM Peraturan Daerah No. 2/2004 belum memuat ketentuan mengenai lama dan biaya pengurusan serta pelaku usaha mana saja yang wajib 
mengurus perizinan tersebut. Selain itu Peraturan Daerah No. 14 Tahun 2008 tentang Retribusi Izin Usaha Perikanan. Pemerintah telah mengambil langkah dalam rangka mewujudkan kesejahteraan nelayan di Kabupaten Flores Timur dengan dikeluarkannya Peraturan Daerah Kabupaten Flores Timur No. 5 Tahun 2019 tentang Perlindungan dan pemberdayaan nelayan kecil. Namun kesadaran nelayan di Flores Timur tentang regulasi perizinan operasi penangkapan ikan masih banyak nelayan belum mengetahui adanya regulasi ini dan banyak nelayan yang berlayar tanpa surat izin. Dan masih lemahnya fungsi pengawasan dari pemerintah terhadap kegiatan perikanan.

\section{- Supporting Pendanaan dan In- vestasi}

Berdasarkan kondisi yang terjadi di lapangan, bahwa fungsi terkait (Supporting) pendanaan dan investasi pada bidang perikanan belum berjalan baik. Hal ini terlihat dari program optimalisasi pengembangan perikanan tangkap oleh pemerintah di Kabupaten Flores Timur yang masih belum bisa dirasakan secara menyeluruh terhadap pelaku kegiatan perikanan.

\section{- Advokasi dan Diplomasi}

Pengertian advokasi adalah suatu bentuk tindakan yang mengarah pada pembelaan, memberi dukungan, atau rekomendasi berupa dukungan aktif. Advokasi juga dapat diartikan sebagai suatu bentuk upaya untuk memengaruhi kebijakan publik dengan melakukan berbagai macam pola komunikasi yang persuasif. Secara sempit, definisi advokasi adalah kegiatan pembelaan hukum atau litigasi yang dilakukan oleh pengacara dan merupakan pekerjaan yang berkaitan dengan praktik beracara di pengadilan. Advokasi melibatkan berbagai strategi yang ditujukan untuk memengaruhi pengambilan keputusan baik di tingkat lokal, nasional maupun di tingkat Internasional.
Berdasarkan hasil analisis, maka dapat disimpulkan bahwa masih lemahnya fungsi advokasi dan diplomasi untukpengembangan sektor perikanan di Kabupaten Flores Timur.

\section{- Pengembangan Dukungan Infra- struktur}

Digambarkan bahwa adanya dukungan dari pemerintah terkait capaian program yang telah dilakukan lewat pembenahan infrastruktur pendukung kegiatan perikanan di Kabupaten Flores Timur.

Berdasarkan hasil pengamatan, data dan hasil wawancara yang dilakukan, dapat disimpulkan bahwa masih lemahnya kebijakan dalam pengembangan dukungan infrastruktur yang mendukung pengembangan sektor perikanan di Kabupaten Flores Timur. Karena masih belum bisa dirasakan secara baik masyarakat Kabupaten Flores Timur.

\section{Faktor yang Menjadi Kendala dalam Pengembangan Sektor Perikanan}

Berikut beberapa faktor yang dapat disimpulkan penulis dalam penelitian berdasarkan pengamatan dan hasil wawancara antara lain:

\section{- Sumber Daya Ikan}

Potensi pemanfaatan perikanan di Kabupaten Flores Timur masih didominasi dari jenis ikan tuna tertentu saja antara lain jenis tuna sirip kuning (Yellow Fin Taill Tuna) dan tuna mata besar (Big Eye Tuna), karena keterbatasan armada tangkap beroperasi di atas $20 \mathrm{GT}$.

Berdasarkan data produksi Dinas Perikanan Kabupaten Flores Timur 2019, jumlah maksimum yang boleh ditangkap dan tidak merusak kelestarian sumber daya daerah (Maximum Sustainable Year) adalah 11.254 ton. pada 2019 produksi hasil perikanan laut di Kabupaten Flores Timur sebesar $14.170,81$ ton, sedangkan potensinya sebesar $18.858,99$ ton. Dengan 
demikian usaha penangkapan ikan di laut telah mencapai 75,14 \%. Potensi sektor perikanan di Kabupaten Flores Timur terdiri dari potensi usaha perikanan tangkap pada sungai dan waduk, potensi budi daya perikanan air tawar pada kolam dan keramba, potensi sumber air dan tanah yang mempunyai kualitas baik untuk budi daya perikanan.

\section{- Produksi Ikan}

Data produksi ikan tangkap di Kabupaten Flores Timur pada 2017 sebanyak 3.772 ton. Pada 2018 berjumlah 3.468,7 ton. Sedangkan tahun 2019 total produksi yang diantarpulaukan sebesar 5.013, 6 ton. Berdasarkan hasil pengamatan bahwa produksi perikanan di Kabupaten Flores Timur cenderung meningkat namun tidak mengalami kenaikan secara signifikan.

\section{- Sumber Daya Manusia}

Sumber daya manusia merupakan unsur utama pembangunan yang perlu diperhatikan dalam proses pengembangan Sektor perikanan daerah di Kabupaten Flores Timur, di samping dua unsur lainnya, yaitu teknologi dan sumber daya alam. Termasuk ke dalam sumber daya manusia ini adalah sumber daya manusia sebagai pengelola manajemen (Aparatur Pemerintahan Daerah), penghasil teknologi maupun sumber daya pengguna teknologi.

Berdasarkan hasil pengamatan di lapangan, dapat disimpulkan bahwa SDM Nelayan di Kabupaten Flores Timur masih rendah. Perlu adanya program dari pemerintah secara dalam hal ini adanya diklat atau pelatihan yang lebih baik lagi dan sifatnya berkala bagi nelayan sehingga mampu meningkatkan produksi perikanan ke depannya.

\section{- Sarana dan Prasarana}

Dalam pengembangan perikanan di wilayah Kabupaten Flores Timur masih mengalami berbagai kendala dalam hal daya dukung Sarana dan prasarana dalam penangkapan ikan serta keterbatasan sarana pengawasan dari pemerintah.

Kondisi Sarana dan Prasarana yang digunakan sampai saat ini dalam proses pengembangan perikanan di Kabupaten Flores Timur masih dapat dibilang sangat minim dan tradisional. Dan masih kurangnya sarana pengawasan dari pemerintah terkait pengembangan sektor perikanan.

\section{- Pemasaran}

Pemasaran ikan hanya didominasi pada tingkat pasaran lokal disebabkan penanganan hasil tangkapannya masih belum optimal dan masih terbatasnya (supplier eksportir) yang mendistribusikan atau mengantarpulaukan hasil tangkapannya sampai ke tingkat mancanegara.

Pemanfaatan hasil tangkapan nelayan Flores Timur selama ini untuk konsumsi lokal 52\%, antarpulau 26\% dan Ekspor $22 \%$. Agar ikan tetap segar maka nelayan melakukan penanganan dengan sistem peng-es-an dalam cold box yang sudah tersedia di kapal. Sebagian besar ada juga nelayan yang mengolah hasil tangkapan untuk dijadikan kerupuk ikan/udang. Usaha ini bersifat usaha skala kecil (rumah tangga) dan dipasarkan hanya terbatas bagi penduduk setempat. Di samping itu juga pernah dilakukan pembuatan abon ikan, tetapi karena keterbatasan modal, usaha ini tidak bisa dilanjutkan.

\section{- Aspek Ekonomi}

Pendapatan nelayan masih tidak merata sepanjang musim. Karena tingginya biaya operasional penangkapan ikan. Berdasarkan situasi problematis tersebut, sektor perikanan yang merupakan salah satu potensi yang besar dalam memberikan konrtibusinya terhadap penerimaan Pendapatan Asli Daerah hendaknya pula dapat meningkatkan pendapatan nelayan di Kabupaten Flores Timur. Rendahnya/ ketimpangan distribusi pendapatan nelayan 
miskin sebagai metaproblem dari situasi problematis yang dihadapi khususnya pada sektor perikanan tersebut, sesungguhnya bersumber pada substantif problem, yaitu adanya sekelompok anggota masyarakat (nelayan miskin) yang secara struktural tidak mempunyai peluang dan kemampuan yang memadai untuk mencapai tingkat hidup yang layak. Akibatnya nelayan miskin tersebut harus mengakui keunggulan kelompok masyarakat lainnya dalam persaingan mencari nafkah dan pemilikan aset usaha (produktif), sehingga semakin lama semakin tertinggal.

Oleh karena itu, pendapatan nelayan yang berada di Kabupaten Flores Timur menjadi beragam. Secara pasti sangat sulit untuk ditentukan karena tergantung dari hasil tangkapan perbulannya. Salah satu penyebabnya pemasaran hasil tangkap perikanan selama ini lebih dominan di kalangan lokal dan perlu adanya campur tangan dari pemerintah terkait pemasaran sehingga hasil dari Perikanan Kabupaten Flores Timur bisa dikenal sampai ke mancanegara sehingga mampu mendatangkan keuntungan yang lebih baik.

\section{Strategi Pengembangan Sektor Perikanan dalam Meningkatkan Pendapatan Asli Daerah (PAD)}

Untuk mendapatkan strategi dalam Pengembangan Sektor Perikanan di Kabupaten Flores Timur, maka dalam penelitian ini peneliti menggunakan metode analisis SWOT (Strengths, Weakness, Opportunities dan Threats) dan menggunakan Litmus Test untuk menganalisis tingkat kestrategisan suatu isu yang dihasilkan dari analisis SWOT (Rangkuti: 2016).

\section{- Identifikasi Lingkungan Internal}

\section{Kekuatan (Strengths)}

Dari hasil wawancara dan pengamatan pada saat penelitian, maka peneliti dapat menyimpulkan bahwa faktor yang menjadi kekuatan dalam pengembangan perikanan tangkap antara lain:

1. Potensi perikanan Kabupaten Flores Timur.

2. Geografis Kabupaten Flores Timur yang strategis.

3. Sebagian besar penduduk Flores Timur yang bermatapencaharian sebagai nelayan.

4. Kebijaksanaan Otonomi Daerah.

\section{Kelemahan (Weakness)}

Berdasarkan hasil pengamatan dan wawancara yang dilakukan oleh peneliti, maka ditemukanlah adanya beberapa faktor kelemahan dalam proses pengembangan sektor perikanan tangkap di Kabupaten Flores Timur di antaranya;

1. Sumber Daya Manusia (SDM) yang masih lemah.

2. Kurangnya teknologi pemanfaatan hasil perikanan.

3. Masih kurangnya infrastruktur pendukung.

4. Kurangnya permodalan untuk jumlah nelayan yang tergolong sangat banyak.

5. Masih rendahnya perhatian dari pemerintah terhadap kegiatan perikanan.

6. Kurangnya sarana dan prasarana dalam kegiatan perikanan.

\section{- Identifikasi Lingkungan Eksternal Peluang (Opportunities)}

Berdasarkan hasil pengamatan dan wawancara yang dilakukan oleh peneliti, maka ditemukanlah adanya beberapa faktor peluang apabila proses pengembangan sektor perikanan tangkap di Kabupaten Flores Timur:

1. Hasil perikanan Kabupaten Flores Timur dapat dikenal sampai pasar internasional. 
2. Terbentuknya iklim investasi perikanan secara baik.

3. Makin luasnya pasar yang berpeluang terciptanya kemitraan antardaerah.

4. Meningkatnya Pendapatan asli Daerah (PAD) Kabupaten Flores Timur.

\section{Ancaman (Threats)}

Berdasarkan hasil pengamatan dan wawancara yang dilakukan oleh peneliti, maka ditemukanlah adanya beberapa faktor ancaman dalam proses pengembangan sektor perikanan tangkap di Kabupaten Flores Timur. Peneliti dapat menyimpulkan sebagai berikut.

1. Terjadinya kegiatan Ilegal Fishing.

2. Adanya konflik penguasaan sumber daya.

3. Perekonomian Kabupaten Flores Timur yang masih rentan tidak stabil.

4. Timbulnya pasar gelap perikanan.

5. Rendahnya dukungan permodalan.

\section{SIMPULAN}

Pengembangan yang dilakukan selama ini hanya lewat bantuan langsung saja terhadap kegiatan perikanan yang ada di Kabupaten Flores Timur. Namun bantuan pengembangan yang diberikan tidak dapat dirasakan secara menyeluruh oleh pelaku di bidang perikanan atau pengembangan yang dilakukan belum maksimal. Hal ini juga bisa dilihat juga di mana fungsi pengawasan terhadap kegiatan perikanan belum secara baik dilakukan oleh pemerintah dan belum maksimalnya pengembangan hasil produksi perikanan secara baik lewat pengolahan secara berkelanjutan. Potensi perikanan belum mampu memberikan kesejahteraan yang memadai bagi seluruh masyarakat nelayan sebagai pelaku utama dan belum memberikan kontribusi yang menggembirakan bagi Pendapatan Asli Daerah (PAD) Kabupaten Flores Timur.
Ada beberapa kendala yang dihadapi dalam pengembangan perikanan di Kabupaten Flores Timur di mana di antaranya aspek sumber daya ikan, aspek produksi, aspek Sumber Daya Manusia (SDM) yang masih lemah, aspek sarana dan prasarana dalam kegiatan perikanan, aspek pemasaran, dan aspek ekonomi.

\section{SARAN}

Dinas Perikanan perlu menerapkan alternatif strategi yang telah diuraikan pada hasil penelitian ini dalam mengatasi permasalahan yang ada sebagai dampak dari pengembangan perikanan tangkap dalam meningkatkan Pendapatan Asli Daerah (PAD).

\section{DAFTAR RUJUKAN}

Alimuddin, 2006, Konflik Etnik: Peran Pemerintah Daerah Dalam Penyelesaian Konflik Sosial, Alqaprint, Sumedang.

Arikunto, Suharsimi, 2013. Prosedur penelitian (Suatu pendekatan Praktik), Rineka Cipta. Jakarta.

Bryson, John, M, 2016, Perencanaan Strategis Bagi Organisasi Sosial. Pustaka Pelajar, Yogyakarta.

Creswell, Jhon w, 2014. Research Design (Pendekatan Kualitatif, Kuantitatif dan Mixed) Edisi Ketiga, Pustaka Pelajar. Yogyakarta.

Damanik, Janianton, 2013. Pariwisata Indonesia. Yogyakarta: Pustaka Pelajar.

Effendi, Irzal. 2004. Pengantar Akuakultur. Jakarta: Penebar Swadaya.

, (2010) Komunikasi Teori dan Praktik. Jakarta: PT Grasindo Rosdakarya.

Fauzi, Akhmad, 2005, Kebijakan Perikanan dan Pembangunan--Isu, Sintesis dan Gagasan, PT Gramedia Pustaka Utama, Jakarta.

Hadari, Nawawi. 2007. Manajemen Sumber Daya Manusia Untuk bisnis Yang Kompetitif. Yogyakarta Gajah Mada University Press. 
Heenne, Aime. Dkk, 2010, Manajemen Strategis Keorganisasian Publik, PT Refika Aditama, Bandung.

Hubeis dan Najib, 2008. Manajemen Strategis Dalam Pengembangan Daya Saing Organisasi, Elex Media Komputindo, Jakarta.

Irawan Soehartono, Metodologi penelitian Sosial suatu Teknik penelitian Bidang Kesejahteraan Sosial dan Ilmu Sosial Lainnya, Rosdakarya, Bandung.

Kusumastanto, Tridoyo, 2003, Ocean Policy dalam Membangun negeri Bahari, PT Gramedia Pustaka Utama, Jakarta.

Koirudin. 2005. Kebijaksanaan Desentralisasi di Indonesia Format Masa Depan Menuju Kemandirian Daerah Sketsa. Malang: Averroes Press.

2007. Ekonomi Kelautan (Ocean Economics). Pusat Kajian Sumber daya Pesisir dan Lautan, Institut Pertanian Bogor, Bogor.

Lexy J. Moleong, 2014, Metodologi Penelitian Kualitatif (Edisi Revisi), Remaja Rosdakarya, Bandung.

Mahmudi, 2010. Analisis Laporan keuangan Pemerintah Daerah. Yogyakarta: Sekolah Tinggi Ilmu Manajemen YKPN.

Nazir, Moh. 2013. Metode penelitian, Ghalia Indonesia. Bogor.

Ndraha, Taliziduhu. 2011, Kybernologi (Ilmu Pemerintahan Baru), Rineka Cipta, Jakarta.

Oktariza dan Effendi, 2006, Manajemen Agribisnis Perikanan, Penebar Swadaya, Jakarta.

Prawoto, Agus. 2011. Penilaian Pajak Bumi Bangunan Perdesaan dan Perkotaan. Yogyakarta. BPFE.
Rangkuti, Freddy. 2016, Teknik Membedah Kasus Bisnis Analisis SWOT, Gramedia Pustaka Utama. Jakarta.

Rasyid, M. Ryaas. 2007, Makna Pemerintahan, Mutiara Sumber Widya, Jakarta.

Rosidin, Utang. 2010. Otonomi Daerah dan Desentralisasi. Bandung: Pustaka Setia.

Sedarmayanti, 2009, Sumber Daya Manusia dan Produktivitas Kerja. Bandung: Penerbit Mandar Maju. , 2014. Manajemen Strategi, PT Refika Aditama, Bandung

Simangunsong, 2016. Metodologi Penelitian Pemerintahan (teoretis-LegalistikEmpiris-inovatif), alfabeta, Bandung.

Sidik, Machfud, 2002. Perimbangan Keuangan Pusat dan Daerah sebagai Pelaksanaan Desentralisasi Fiskal (antara Teori dan Aplikasinya di Indonesia). Seminar "Setahun Implementasi Kebijaksanaan Otonomi Daerah di Indonesia".

Subri, M. 2007. Ekonomi kelautan. PT raja grafindo persada. Jakarta.

Sugiyono, 2017. Metode Penelitian (Kuantitatif, Kualitatif, dan RD), alfabeta. Bandung.

Suharsimi Arikuntoro, 2003. Prosedur Penelitian (Suatu Pendekatan Praktik), Rineka Cipta, Jakarta.

Utang Rosidin,2015. Otonomi daerah dan desentralisasi. Bandung: Cv Pustaka Setia.

Wasistiono, Sadu. 2002. Penyelenggaraan Pemerintahan Daerah. Bandung: Fokusmedia.

Sadu Wasistiono \& Fernandes Simangunsong (2015), Metodologi Ilmu Pemerintahan (edisi yang diperluas), IPDN.

Yusuf, Murik 2014. Metode penelitian (Kuantitatif, Kualitatif, dan Penelitian Gabungan), Pranadamedia Group. Jakarta. 
Virioner - Vol. $13 \backslash$ No. $2 \backslash$ Agustus 2021 